\title{
Hardwood Cutting Propagation of Confederate Rose Using Auxin and Wounding Treatments
}

\author{
Eugene K. Blythe ${ }^{1}$
}

\begin{abstract}
AdDitional Index words. Hibiscus mutabilis, rose cottonmallow, dixie rosemallow, vegetative propagation, root-promoting compounds

SuMmary. Confederate rose (Hibiscus mutabilis), a native of southeastern China, is an old-fashioned, ornamental plant often found in older gardens in the southern United States. Current breeding programs aim at developing selections with improved garden performance, thus providing new cultivars for nursery production. Hardy in U.S. Department of Agriculture (USDA) zones 7 to 9, plants grow as large shrubs or small trees in warmer areas, but generally die back to a woody base or short trunk in colder areas of their range. Stems from the past growing season that remain on plants during the winter in the warmer regions may be used to prepare hardwood stem cuttings. The current study examined hardwood cutting propagation of confederate rose in response to a 1 -second basal quick-dip in auxin [1000 ppm indole-3-butyric acid (IBA), 3000 ppm IBA, 1000 ppm IBA + 500 ppm 1-naphthaleneacetic acid (NAA), and 3000 ppm IBA + 1500 ppm NAA] and a basal wound (along with $1000 \mathrm{ppm}$ IBA only). Cuttings were rooted in a warm, high-humidity environment within a greenhouse. Auxin treatments improved overall rooting percentage and total root length, with $1000 \mathrm{ppm}$ IBA (without and with a basal wound) providing the highest rooting percentages (about $70 \%$ ) and nontreated cuttings the lowest (44\%). A significant increase in total root length on rooted cuttings resulted with the use of $3000 \mathrm{ppm} I B A(211 \mathrm{~cm})$ and use of a basal wound plus 1000 ppm IBA $(193 \mathrm{~cm})$ compared with nontreated cuttings $(87 \mathrm{~cm})$. Auxin and wounding treatments did not have any significant inhibitory effects on budbreak and growth of new shoots on rooted cuttings.
\end{abstract}

C onfederate rose, also known as cottonmallow or dixie rosemallow, is an old-fashioned plant that was once commonly grown throughout the southern United States, although the species is native to southeastern China (Flora of China Editorial Committee, 2006; Scheper, 2003; Welch, 2009). Often considered a "pass-along" plant because of its distribution through friends and neighbors, confederate rose is popular for its large, soft, gray-green foliage during the summer, and large, showy flowers produced late in the

Assistant Research Professor, Coastal Research and Extension Center, Mississippi State University, South Mississippi Branch Experiment Station, Poplarville, MS 39470

Thanks to Scott Langlois, Eric Stafne, and Anthony Witcher for reviewing an early draft of this manuscript. Thanks also to Cecil Pounders for providing the cutting material and to Dip 'N Grow Inc. for providing the auxin-containing products used in this study. This article was approved for publication as Journal Article No. J-12151 of the Mississippi Agricultural and Forestry Experiment Station, Mississippi State University.

Mention of trade names or commercial products in this article is solely for the purpose of providing specific information and does not imply recommendation or endorsement to the exclusion of other products that may also be suitable.

${ }^{1}$ Corresponding author. E-mail: blythe@pss.msstate.edu. season when few other plants are in bloom (Russ, 2007).

Confederate rose is hardy in USDA zones 7 to 9 (Scheper, 2003). Plants grow as large shrubs or small trees in warmer areas, dropping their leaves in winter and leafing out on old stems in the spring (Russ, 2007). Plants behave more like herbaceous perennials in the colder parts of their hardiness range, producing new flowering branches from a woody base or short trunk each year (Editors of Sunset Books and Sunset Magazine, 1997). Plants will grow to $15 \mathrm{ft}$ high and $10 \mathrm{ft}$ wide in frost-free areas and 6 to $8 \mathrm{ft}$ in areas with hard freezes (Knox and Schoellhorn, 2011).

Plants of confederate rose flower from late summer to early fall, with flowers clustered near the ends of the branches (Liberty Hyde Bailey Hortorium, 1976; Scheper, 2003). The 6- to 10-inch-wide flowers open white or pink and darken as they age over about $3 \mathrm{~d}$, resulting in multiple flower colors on the same plant. Commonly grown cultivars are Flora Plena, with double white flowers, and Rubra, of shorter stature and with deep pink to carmine flowers (Knox and Schoellhorn, 2011).

Confederate rose has been used in breeding programs to produce interspecific hybrids (Wise, 1973). Current hybridization efforts at the USDA-Agricultural Research Service (ARS) Thad Cochran Southern Horticultural Laboratory in Poplarville, MS, aim to develop clonal selections with improved garden performance, reduced plant height, improved disease resistance, and prolific flower production (C.T. Pounders, personal communication). Based on this author's experience in commercial nursery propagation, clonal selections of confederate rose may be readily propagated using leafy, semihardwood stem cuttings during the growing season. Confederate rose may also be propagated by tissue culture (Shahzad et al., 2001).

Stem cuttings of confederate rose are reported to root readily (Scheper, 2003), including cuttings taken in the fall (Russ, 2007); however, the requirement of an auxin treatment to promote rooting of the cuttings has not been noted. Comparing rooting of softwood and hardwood cuttings of confederate rose during the winter, spring, and monsoon seasons in India, Pandey and Vaish (1990) determined that optimal rooting could be obtained using hardwood cuttings in the winter. These authors did not report using any auxin treatment.

Propagation of confederate rose from hardwood cuttings collected from stock plants during the winter in areas where stems from the previous season's growth are not killed

\begin{tabular}{llll}
\hline $\begin{array}{l}\text { Units } \\
\text { To convert U.S. to SI, } \\
\text { multiply by }\end{array}$ & U.S. unit & SI unit & $\begin{array}{l}\text { To convert SI to U.S., } \\
\text { multiply by }\end{array}$ \\
\hline 0.3048 & $\mathrm{ft}$ & $\mathrm{m}$ & 3.2808 \\
2.54 & inch(es) & $\mathrm{cm}$ & 0.3937 \\
25.4 & inch(es) & $\mathrm{mm}$ & 0.0394 \\
16.3871 & inch & $\mathrm{cm}^{3}$ & 0.0610 \\
1 & ppm & $\mathrm{mg} \cdot \mathrm{L}^{-1}$ & 1 \\
$\left({ }^{\circ} \mathrm{F}-32\right) \div 1.8$ & ${ }^{\circ} \mathrm{F}$ & ${ }^{\circ} \mathrm{C}$ & $\left(1.8 \times{ }^{\circ} \mathrm{C}\right)+32$
\end{tabular}


by cold winter temperatures would permit maximum use of propagation material for the rapid multiplication of new cultivars by supplementing, or being used in place of, leafy stem cuttings taken during the growing season. Therefore, the objective of the present study was to examine the need for an auxin treatment and basal wounding treatment to optimize rooting of hardwood cuttings of confederate rose. Auxin treatments are commonly used in commercial plant propagation to increase overall rooting percentages, hasten root initiation, increase the number and quality of roots, and encourage uniformity of rooting (Hartmann et al., 2002; Macdonald, 1987). Hardwood cuttings of some ornamental species root readily without any auxin treatment, eliminating one step in commercial propagation (Blythe and Sibley, 2009). Application of auxin is sometimes carried out in conjunction with a wounding treatment to expose more of the cambium tissue to the auxin (Blythe et al., 2007).

\section{Materials and methods}

This experiment was initiated with collection, preparation, treatment, and placement of cuttings on 4 Feb. 2008. Cutting propagation material was collected from mature plants of 18 different, unnamed clones (each clone serving as a block) of confederate rose under evaluation in a breeding program and growing in field rows at the USDA-ARS Thad Cochran Southern Horticultural Laboratory (lat. $30^{\circ} 50^{\prime} 26^{\prime \prime} \mathrm{N}$, long. $89^{\circ} 32^{\prime} 46^{\prime \prime} \mathrm{W}$; USDA hardiness zone $8 \mathrm{~b})$. Subterminal cuttings were prepared 4.75 to 5.50 inches in length with four vegetative buds, trimming 0.5 inch above and below a vegetative bud. Caliper of the cuttings ranged from 0.35 to $0.40 \mathrm{inch}$.

Auxin solutions were prepared by diluting Dip 'N Grow $(10,000$ ppm IBA + 5000 ppm NAA; Dip 'N Grow, Clackamas, OR) and Dip 'N Grow Lite (an experimental product with 10,000 ppm IBA; Dip 'N Grow) with isopropyl alcohol and deionized water to produce a final solution containing $50 \%$ alcohol. Cuttings in one treatment remained untreated, whereas cuttings in all other treatments received a 1 -s basal quick-dip to a depth of 0.6 inch in their respective auxin treatments (1000 ppm
IBA, 3000 ppm IBA, 1000 ppm IBA + 500 ppm NAA, 3000 ppm IBA + $1500 \mathrm{ppm} \mathrm{NAA})$. In an additional treatment, cuttings were wounded by making a vertical incision to remove a wedge of bark 0.5 inch in length (penetrating slightly into the wood at the base of the cutting) on two opposing sides of the cutting base, followed by a basal quick-dip in 1000 ppm IBA solution. Treatments were randomly assigned to cuttings within each clone. Cuttings were inserted to a depth of 1 inch into individual cells of six-packs (TJ606 jumbo inserts, 11.5 inch $^{3}$ /cell; Dillen Plastics, Middlefield, $\mathrm{OH}$ ) containing a commercial blend of peat, perlite, vermiculite, and pine bark (Fafard 3B; Conrad Fafard, Agawam, MA) as the rooting substrate.

Cuttings were placed inside a 4 -ft-wide by 8 -ft-long by 3 -ft-high polyethylene-covered enclosure (to maintain high humidity) within a climate-controlled greenhouse with an interior, retractable shade curtain. Overhead mist was provided within the rooting enclosure by three $2.8-\mathrm{mm}$ orifice nozzles (Pin-Perfect; Dramm Corp., Manitowoc, WI) spaced $3 \mathrm{ft}$ apart and raised $\mathrm{l} \mathrm{ft}$ above the cuttings. Overhead mist was supplied hourly for $10 \mathrm{~s}$ to maintain a relative humidity $>60 \%$. Maximum photosynthetically active radiation in the enclosure at the level of the cuttings was 310 $\mu \mathrm{mol} \cdot \mathrm{m}^{-2} \cdot \mathrm{s}^{-1}$. Daily maximum and minimum temperatures were $79 \pm 9$ and $63 \pm 5{ }^{\circ} \mathrm{F}$, respectively. Temperature and humidity were monitored with a data logger (HOBO Pro RH/Temp; Onset Computer Corp., Bourne, MA) placed with the cuttings.

A general block design was used with clone as the blocking factor and six cuttings (replications) per treatment per clone (for a total of 108 cuttings per treatment). Number of rooted cuttings, total length of primary roots on each rooted cutting, number of new shoots on each rooted cutting, and total shoot length on each rooted cutting were determined after a rooting period of $54 \mathrm{~d}$. A cutting was considered to be rooted if it had at least one root $>1$ inch in length. Root systems were washed to remove substrate and digitally scanned for analysis using WinRhizo software (Regent Instruments, Quebec, QC, Canada) to determine total root length.
Data were analyzed using generalized linear mixed models with the GLIMMIX procedure of SAS (version 9.2; SAS Institute, Cary, NC). Rooting was modeled using the binary distribution with the logit link function, number of new shoots was modeled using the Poisson distribution and the log link function, and total root length and total shoot length were modeled using the normal distribution and the identity link function. Probability values for pairwise comparisons of means were adjusted using the Shaffer-Simulated method to control for an experimentwise significance level of 0.05 . Linear contrasts were used to compare the mean responses of nontreated cuttings with the combined responses of cuttings receiving the four rates of auxin (excluding wounded cuttings), thus providing an overall assessment of the value of an auxin application.

\section{Results and discussion}

Rooting percentage was improved overall with the use of a basal quick-dip in an auxin solution in comparison with nontreated cuttings (Table 1). Examining specific treatments, 1000 ppm IBA (both without and with a basal wound) enhanced rooting percentage in comparison with nontreated cuttings, whereas higher rates of auxin (either IBA alone or $\mathrm{IBA}+\mathrm{NAA}$ ) did not result in as great an improvement. This indicates that use of a basal quick-dip in auxin will enhance rooting percentage, with the lowest rate (1000 ppm IBA, which resulted in $69 \%$ rooting) being satisfactory and not improved by additional use of a basal wound.

Total root length was greatest overall with the use of an application of auxin in comparison with nontreated cuttings (Table 1). Among the specific treatments, cuttings treated with $3000 \mathrm{ppm}$ IBA, as well as wounded cuttings treated with 1000 ppm IBA, exhibited significantly greater total root length than nontreated cuttings. These responses indicate that the moderate rate of auxin (3000 ppm) promoted development of a larger root system compared with no auxin treatment; however, a response similar to that obtained using 3000 ppm IBA could be achieved using the $1000 \mathrm{ppm}$ rate of auxin along with a basal wound. Nevertheless, root systems among all cuttings 
Table 1. Rooting and initial shoot development responses of subterminal, hardwood stem cuttings of confederate rose treated with and without a basal quick-dip in an auxin solution [indole-3-butyric acid (IBA) or IBA + 1-naphthaleneacetic acid (NAA)], plus one treatment using a basal wound, along with a statistical comparison of nontreated cuttings with the overall response of auxin-treated cuttings. ${ }^{2}$

\begin{tabular}{|c|c|c|c|c|}
\hline Auxin rate $(\mathrm{ppm})^{\mathrm{y}}$ & $\begin{array}{c}\text { Rooted } \\
\text { cuttings (\%) }\end{array}$ & $\begin{array}{c}\text { Total root } \\
\text { length }(\mathrm{cm})^{\mathrm{x}}\end{array}$ & $\begin{array}{c}\text { New } \\
\text { shoots }(\text { no. })^{\mathrm{x}}\end{array}$ & $\begin{array}{c}\text { Total length of } \\
\text { new shoots }(\mathrm{cm})^{x}\end{array}$ \\
\hline Nontreated & $44 \mathrm{~b}^{\mathrm{w}}$ & $87 \mathrm{~b}$ & $2.0 \mathrm{a}$ & $9.4 \mathrm{ab}$ \\
\hline 3000 IBA & $59 \mathrm{ab}$ & $211 \mathrm{a}$ & $1.7 \mathrm{a}$ & $13.1 \mathrm{a}$ \\
\hline $1000 \mathrm{IBA}+500 \mathrm{NAA}$ & $60 \mathrm{ab}$ & $159 \mathrm{ab}$ & $1.7 \mathrm{a}$ & $10.9 \mathrm{ab}$ \\
\hline $3000 \mathrm{IBA}+1500 \mathrm{NAA}$ & $61 \mathrm{ab}$ & $145 \mathrm{ab}$ & $1.5 \mathrm{a}$ & $8.5 \mathrm{~b}$ \\
\hline
\end{tabular}

${ }^{2}$ Cuttings were prepared 4.75 to 5.50 inches in length and inserted to a depth of 1 inch into a commercial blend of peat, perlite, vermiculite, and pine bark in a warm, highhumidity rooting environment inside a greenhouse for a rooting period of $54 \mathrm{~d}$ ( 1 inch $=2.54 \mathrm{~cm}$ ). There were six cuttings per treatment for each of $18 \mathrm{clones}$ (blocking factor), providing a total of 108 cuttings per treatment.

${ }^{y} 1 \mathrm{ppm}=1 \mathrm{mg} \cdot \mathrm{L}^{-1}$

Rooted cuttings only; $1 \mathrm{~cm}=0.3937$ inch

${ }^{w}$ Means followed by the same letter within a column are not significantly different according to the Shaffer-Simulated method $(\alpha=0.05)$.

vAuxin-treated includes four treatments: 1000 ppm IBA, 3000 ppm IBA, 1000 ppm IBA + 500 ppm NAA, and 3000 ppm IBA + 1500 ppm NAA. Cuttings receiving the basal wound were excluded. Probability value for the test that the difference between the nontreated and auxin-treated cuttings is zero. Small values (generally less than 0.05 ) indicate a significant difference.

receiving the various auxin treatments were visually noted to be of adequate size for holding together the volume of substrate if removed from the cells, indicating that the lower rate of auxin would be satisfactory for producing root systems of suitable size over the 54 -d rooting period used in this study.

The number of shoots that developed from the rooted cuttings and their total length was not significantly affected by auxin application or wounding in comparison with nontreated cuttings (Table 1 ). With one exception for total shoot length response, treatments means for number of shoots and total shoot length were similar among the individual treatments. These results indicate that auxin treatments used in this study did not have an inhibitory effect on budbreak or shoot development on the rooted cuttings, an effect that can occur on stem cuttings of some crops, depending upon the type and concentration of auxin being used (Blythe et al., 2007).

\section{Literature cited}

Blythe, E.K. and J.L. Sibley. 2009. Winter stem cutting propagation of 'Dwarf Burford' holly without use of a conventional auxin treatment. HortTechnology 19: 130-132.

Blythe, E.K., J.L. Sibley, K.M. Tilt, and J.M. Ruter. 2007. Methods of auxin application in cutting propagation: A review of 70 years of scientific discovery and commercial practice. J. Environ. Hort. 25:166-185.

Editors of Sunset Books and Sunset Magazine. 1997. Sunset national garden book. Sunset Books, Menlo Park, CA.

Flora of China Editorial Committee. 2006. Flora of China. Vol. 12. Missouri Botanical Garden Press, St. Louis.

Hartmann, H.T., D.E. Kester, F.T. Davies, Jr., and R.L. Geneve. 2002. Hartmann and Kester's plant propagation: Principles and practices. 7th ed. Prentice Hall, Upper Saddle River, NJ.

Knox, G.W. and R. Schoellhorn. 2011. Hardy hibiscus for Florida landscapes. Florida Coop. Ext. Serv. Publ. ENH999.
Liberty Hyde Bailey Hortorium. 1976. Hortus third. Macmillan, New York.

Macdonald, B. 1987. Practical woody plant propagation for nursery growers. Timber Press, Portland, OR.

Pandey, D.S. and U.S. Vaish. 1990. Season, media and type of wood for propagation of Hibiscus L. Indian J. For. 13:307-311.

Russ, K. 2007. Hibiscus. Clemson Univ. Coop. Ext. Serv. Publ. HGIC 1179.

Scheper, J. 2003. Hibiscus mutabilis. Floridata plant profile \#281. 1 Feb. 2012. <http://www.floridata.com/ref/h/ hibis_mu.cfm $>$.

Shahzad, A., M. Faisal, M. Kashif Husain, and S.A. Siddiqui. 2001. Micropropagation in Hibiscus mutabilis Linn.-An ornamental plant. Bionotes 3(3):69.

Welch, W.C. 2009. Hardy hibiscus. Texas AgriLife Ext. Serv. 1 Feb. 2012. <http:// aggie-horticulture.tamu.edu/southern garden/hibiscus.html>.

Wise, D.A. 1973. Genome relationship of Hibiscus mutabilis. J. Hered. 64:285288. 